\title{
KEDUDUKAN SERTA PERLINDUNGAN HUKUM BAGI PEMEGANG HAK PATEN DALAM KERANGKA HUKUM NASIONAL INDONESIA DAN HUKUM INTERNASIONAL
}

\author{
Oleh: Yoyon M Darusman \\ Program Studi Magister Hukum Universitas Pamulang \\ Email: yoyon.darusman@yahoo.co.id
}

\begin{abstract}
Intellectual Property Rights as a part of property rights which belongs to human. The word property means ideas, creations, imaginations and thought. One of the intellectual property rights involves the field of industry (industrial property rights), especially related to technology which is called Invention, Based on legal perspective, it called as Patent. Patent is the exclusive rights which is given by the state to the inventor as the results of its invention in the field of technology, is given for a periode of time done by himself or appointed to other parties to do it. Then "Invention" is Inventor idea which is applicated in one activity of problem solving which specific in the field of technology, as a product, process, or improvement and development product or process. Then the Patent as one of the other Intellectual Property Rights (IPR) has the importance position to the respective holder and getting protection on national and international law.
\end{abstract}

Keywords: Position, Protection, Patent Holder

\begin{abstract}
Abstrak
Hak Kekayaan Intelektual merupakan bagian dari pada hak kekayaan yang dimiliki oleh manusia. Kekayaan tersebut lahir karena adanya ide, kreasi, imajinasi dan pikiran. Salah satu kekayaan intelektual tersebut dapat dilihat dibidang industri. Khususnya yang berkaitan dengan teknologi yang dalam hal ini disebut dengan paten. Paten merupakan hak ekslusif yang diberikan oleh negara kepada Inventor atas hasil invensinya di bidang teknologi, yang untuk selama waktu tertentu melaksanakan sendiri invensinya tersebut atau memberikan persetujuannya kepada pihak lain untuk melaksanakannya. Selanjutnya invensi adalah ide inventor yang dituangkan ke dalam suatu kegiatan pemecahan permasalahan yang spesifik di bidang teknologi, dapat berupa produk atau proses, atau penyempurnaan dan pengembangan produk atau proses. Sebagai salah satu dari Hak Kekayaan Intelektual (HKI), paten memeliki kedudukan yang sangat penting bagi pemiliknya serta mendapatkan perlindungan dalam kerangka nasional maupun internasional.
\end{abstract}

Kata Kunci: Kedudukan, Perlindungan, Pemegang Hak Paten

\section{A. Pendahuluan}

Dalam sejarah perkembangan hukum di Indonesia khususnya di bidang hukum privat atau hukum perdata, terdapat pengaturan mengenai hak kebendaan. Menurut Pasal 
499 KUH Perdata benda adalah tiap-tiap barang dan tiap-tiap hak yang dapat dikuasai oleh hak milik. Prof Mahadi kemudian menawarkan seandainya dikehendaki rumusan lain dari pasal ini dapat diturunkan kalimat berikut; yang dapat menjadi obyek hak milik adalah benda dan benda itu terdiri dari barang dan hak. (Mahadi, 1981: 65). Berdasarkan pengertian tersebut, dapat disimpulkan bahwa pengertian benda merupakan setiap barang dan hak yang dapat dikuasai oleh seseorang sebagai hak milik. Selanjutnya sebagaimana diterangkan oleh Prof. Mahadi barang yang dimaksudkan oleh pasal 499 KUH Perdata tersebut adalah benda materil, sedangkan hak adalah benda immateril. Uraian ini sejalan dengan klasifikasi benda menurut pasal 503 KUH Perdata (Begerlijk wet Book) yaitu penggolongan benda ke dalam kelompok benda berwujud dan benda tidak berwujud.

Karena hak kebendaan diatur dalam KUH Perdata atau Begerlijk wet Book (BW), maka perlu dipahami bahwa BW terdiri dari 4 (empat) buku yaitu (i) Buku I mengatur tentang Hukum Kekeluargaan (ii) Buku II mengatur tentang Hukum Kebendaan (Titik Tri Wulan Tutik, 2008: 45) (iii) Buku III mengatur tentang Hukum Perikatan dan (iv) Buku IV mengatur tentang Hukum Kepailitan dan Kadaluarsa. Berkenaan dengan Hukum Kebendaan sebagaimana yang diatur dalam Buku II, khususnya yang mengatur tentang hak-hak atas kebendaan hanya dikenal atas hak kebendaan yang berwujud (tangible object) dalam bahasa Belanda disebut dengan istilah "lichamelijk zaak" dan belum mengenal atas hak kebendaan yang tidak berwujud (intangible object) dalam bahasa Belanda disebut dengan istilah "onlichamelijk zaak".

Namun demikian dengan seiring dengan berkembangnya ilmu pengetahuan dan teknologi sejak abad ke 18, hak-hak atas kebendaan bukan saja yang berupa hak atas kebendaan yang berwujud (tangible object) tetapi terdapat juga hak atas kebendaan yang tidak berwujud (intangible object) . Hak Kekayaan Interlektual (HKI) yang di dalam bahasa Inggrisnya disebut dengan Intellectual Property Rights (IPR) termasuk dalam bidang hukum perdata yang merupakan bagian hukum yang mengatur kebendaan. Hak kebendaan terdiri dari atas hak benda materil dan hak benda immateril. Mengenai HKI termasuk hak benda yang tidak berwujud atau immaterial, yang secara garis besar HKI dibagi dalam 2 (dua) bagian yaitu hak cipta (copyrights) dan hak kekayaan industri (industrial property rights) yang mencakup paten (patent), desain insdustri (industrial design), merek (trade 
mark), penanggulangan praktek persaingan curang (repression of unfair competition), desain tata letak sirkuit terpadu (layout design of integrated circuit), dan rahasia dagang (tradesecret). (Monika Suhayati, 2014: 14).

Khusus mengenai paten, maka suatu "paten" diberikan terhadap karya atau ide penemuan (invensi) di bidang teknologi, yang setelah diolah dapat menghasilkan suatu produk maupun hanya merupakan proses saja. (Rachmadi Usman, 2003: 207). Teknologi merupakan suatu bidang yang berkaitan erat dengan hak atas kekayaan cendekiawi,(Oentoeng Soerapati, 1999: 97), khususnya dengan paten dan merek.

Di dalam perkembangan paten di Indonesia masih diperlukan kesadaran dan pemahaman tentang hal-hal penting bagaimana kewajiban pemegang paten untuk mendaftarkan hak-hak yang dimilkinya? Sebab di dalam paten terdapat hak-hak yang melekat, misalnya hak ekslusif, hak ekonomi dan hak moral. (Henry Soelistya, 2013: 125). Hal ini hampir sama dengan hak yang terdapat dalam HKI yang lainnya, misalnya hak cipta dan merek. Merek mengenal hak prioritas. Hak prioritas" (priority rights) yang dalam pelaksanaannya dihubungkan dengan "prinsip pendaftaran pertama" (first to file). Yaitu yang dianggap sebagai pemilih hak adalah pendaftar yang pertama (Oksidelfa Yanto, 2012: 36).

Berdasarkan uraian diatas, maka permasalahan yang hendak dikaji adalah bagaimana kedudukan serta perlindungan hokum bagi pemegang hak paten dalam kerangka hokum nasional dan internasional?

\section{B. Teori Dasar Intellectual Property Rights (IPR)}

Seorang peneliti dalam suatu penelitian hampir selalu menggunakan beberapa teori. Menurut Popper teori adalah ciptaan manusia. Teori hanyalah pendugaan dan pengiraan yang berarti teori tidak pernah benar mutlak. Ilmu baru dapat berkembang jika tiap-tiap teori secara terus-menerus diuji kebenarannya. Cara pengujiannya adalah dengan menunjukkan kesalahan dari teori itu, bukan sebaliknya.(Sidharta, 2009: 59).

Dalam HKI gagasan dasarnya adalah bahwa kekayaan intelektual merupakan milik sang kreator karena kemampuan otaknya. Josef Kohler dengan teorinya yang terkenal dengan "Immaterialguterrecht" menjelaskan, bahwa adanya hubungan yang sangat 
istimewa antara orang dengan benda tak berwujud (immateriales Gut). Menurut Kohler, HKI adalah hak kebendaan yaitu hak atas sesuatu benda yang bersumber dari hasil kerja otak dan hasil kerja rasio atau hasil dari pekerjaan rasio manusia yang menalar. Hasil kerjaannya itu berupa benda immateril (benda yang tidak berwujud). Hasil kerja otak itu kemudian dirumuskan sebagai intelektualitas. Orang yang optimal memerankan kerja otaknya disebut sebagai orang yang terpelajar, mampu menggunakan rasio, mampu berpikir secara rasional dengan menggunakan logika (metode berpikir, cabang filsafat), karena itu hasil pemikirannya disebut rasional atau logis. Orang yang tergabung dalam kelompok ini disebut kaum intelektual.

Sementara itu John Locke dalam teorinya tentang hak milik mengatakan bahwa hak milik dari seorang manusia terhadap benda yang dihasilkannya itu sudah ada sejak manusia itu lahir. John Locke mengemukakan bahwa hukum hak kekayaan intelektual memberikan hak milik eksklusif kepada hasil karya seseorang. (John Locke, 1997: 77). Kemudian Locke menyatakan bahwa hak atas milik pribadi bermula dari kerja manusia dan dengan kerja inilah manusia memperbaiki dunia demi kehidupan yang layak, baik untuk dirinya sendiri maupun orang lain. Asumsi ini mengantar Locke pada suatu pemikiran bahwa kerja individu juga menjadi milik individu. (Marshall Leaffer, 2007: 20). Sedangkan barang adalah benda materil (berwujud) dan hak merupakan benda immateril (tidak berwujud).

\section{Kedudukan Paten Dalam Kerangka Hukum Nasional dan Internasional}

\section{Kerangka Hukum Nasional}

Ketentuan tentang Paten secara umum diatur di dalam Konvensi Paris tentang Perlindungan Kekayaan Industri (protection of industrial property) Pasal 4, 4bis, 4ter, 4 quarter, 5, 5bis, 5ter, 5Quarter, yang ditetapkan pada tanggal 20 Maret 1883. Di dalam Undang-Undang Nomor : 14 Tahun 2015 Tentang Paten secara khusus diatur sebagai berikut : Suatu Invensi dapat diberi Paten jika : Pertama, paten diberikan untuk invensi yang baru dan mengandung langkah inventif serta dapat diterapkan dalam industri. Kedua, suatu invensi mengandung langkah inventif jika invensi tersebut bagi seseorang yang mempunyai keahlian tertentu di bidang teknik merupakan hal yang tidak dapat diduga sebelumnya. Ketiga, penilaian bahwa suatu Invensi merupakan hal yang tidak dapat 
diduga sebelumnya harus dilakukan dengan memperhatikan keahlian yang ada pada saat Permohonan diajukan atau yang telah ada pada saat diajukan permohonan pertama dalam hal Permohonan itu diajukan dengan Hak Prioritas.

Sementara itu suatu invensi dianggap baru jika: Pertama, pada tanggal penerimaan, Invensi tersebut tidak sama dengan teknologi yang diungkapkan sebelumnya. Kedua, teknologi yang diungkapkan sebelumnya, adalah teknologi yang telah diumumkan di Indonesia atau di luar Indonesia dalam suatu tulisan, uraian lisan atau melalui peragaan atau dengan cara lain yang memungkinkan seorang ahli untuk melaksanakan Invensi tersebut sebelum (i) tanggal penerimaan; atau (ii) tanggal prioritas.

Suatu pengecualian dalam Paten bahwa Paten tidak diberikan untuk Invensi tentang : Pertama, proses atau produk yang pengumuman dan penggunaan atau pelaksanaanya bertentangan dengan peraturan perundang-undangan yang berlaku, moralitas agama, ketertiban umum, atau kesusilaan. Kedua, metode pemeriksaan, perawatan, pengobatan dan/atau pembedahan yang diterapkan terhadap manusia dan/atau hewan. Ketiga, teori dan metode di bidang ilmu pengetahuan dan matematika; atau (i) semua mahluk hidup, kecuali jasad renik (ii) proses biologis yang esensial untuk memproduksi tanaman atau hewan, kecuali proses non-biologis atau proses microbiologis.

Jangka waktu perlindungan paten ditentukan sebagai berikut: Pertama, paten diberikan untuk jangka waktu selama 20 (dua puluh) tahun terhitung sejak Tanggal Penerimaan dan jangka waktu itu tidak dapat diperpanjang. Kedua, tanggal mulai dan berakhirnya jangka waktu Paten dicatat dan diumumkan. Ketiga, paten Sederhana (Pasal 6) diberikan untuk jangka waktu 10 (sepuluh) tahun terhitung sejak Tanggal Penerimaan dan jangka waktu itu tidak dapat diperpanjang.

Subjek Paten : Pertama, yang berhak memperoleh Paten adalah Inventor atau yang menerima lebih lanjut hak Inventor yang bersangkutan. Kedua, jika suatu Invensi dihasilkan oleh beberapa orang secara bersama-sama, hak atas Invensi tersebut dimiliki secara bersama-sama oleh para Inventor yang bersangkutan. Ketiga, kecuali terbukti lain, yang dianggap sebagai Inventor adalah orang atau beberapa orang yang untuk pertama kali dinyatakan sebagai Inventor dalam permohonan. 
Permohonan Paten. Pertama, paten diberikan atas dasar Permohonan. Kedua, setiap permohonan hanya dapat diajukan untuk satu invensi atau beberapa Invensi yang merupakan satu kesatuan invensi. Ketiga, permohonan diajukan dengan membayar biaya kepada Direktorat Jenderal. Keempat, permohonan diajukan secara tertulis dalam bahasa Indonesia kepada Direktorat Jenderal.

Penetapan Permohonan, dilakukan: Pertama, Direktorat Jenderal mengumumkan Permohonan yang telah memenuhi ketentuan yang ditetapkan. Kedua, Pengumuman dilakukan : a. Dalam hal paten, segera setelah 18 (delapan belas) bulan sejak Tanggal Penerimaan atau segera setelah 18 (delapan belas) bulan sejak tanggal prioritas apabila Permohonan diajukan dengan Hak Prioritas; atau b. Dalam hal Paten Sederhana, segera setelah 3 (tiga) bulan sejak Tanggal Penerimaan. Ketiga, Pengumuman sebagaimana dimaksud pada ayat (2) huruf a dapat diajukan lebih awal atas permintaan Pemohon dengan dikenai biaya.

Paten diberikan atas dasar Permohonan. Setiap Permohonan hanya dapat diajukan untuk satu Invensi atau beberapa Invensi yang merupakan satu kesatuan Invensi. Permohonan diajukan dengan membayar biaya kepada Direktorat Jenderal HKI. Permohonan diajukan secara tertulis dalam bahasa Indonesia kepada Direktorat Jenderal HKI. Sertifikat Paten merupakan bukti hak atas Paten. Paten mulai berlaku pada tanggal diberikan Sertifikat Paten dan berlaku surut sejak Tanggal Penerimaan. Pemegang paten adalah penemu sebagai pemilik paten atau orang yang menerima hak tersebut dari pemilik paten atau orang lain yang menerima lebih lanjut hak dari orang tersebut di atas, yang terdaftar dalam Daftar Umum Paten. Suatu penemuan dianggap baru, jika pada saat pengajuan permintaan paten penemuan tersebut tidak sama atau tidak merupakan bagian dari penemuan terdahulu. Pemberian hak paten bersifat teritorial, yaitu, mengikat hanya dalam lokasi tertentu.

Upaya hukum terhadap pelanggaran Paten diatur dalam Pasal 19 Undang-Undang Nomor : 14 Tahun 2001 yang menjelaskan bahwa : "Dalam hal suatu produk diimpor ke Indonesia dan proses untuk membuat produk yang bersangkutan telah dilindungi Paten yang berdasarkan Undang-Undang ini. Pemegang Paten-proses yang bersangkutan berhak atas dasar ketentuan dalam Pasal 16 ayat (2) melakukan upaya hukum terhadap produk 
yang diimpor apabila produk tersebut telah dibuat di Indonesia dengan menggunakan proses yang dilindungi Paten."

Hal penting lain yang perlu diperhatikan dalam UU hak paten Tahun 2001 adalah ketentuan yang mengatur mengenai cara mendaftarkan hak paten oleh pemerintah. Dalam hal ini bila pemerintah berpendapat bahwa suatu hak paten di Indonesia sangat penting artinya bagi pertahanan keamanan negara dan kebutuhan sangat mendesak untuk kepentingan masyarakat, maka pemerintah dapat melaksanakan sendiri paten yang bersangkutan. Juga dalam hal pemerintah berpendapat terdapat kebutuhan yang sangat mendesak untuk kepentingan masyarakat atas suatu hak paten, maka pelaksanaannya dapat dilakukan oleh pemerintah. cakupan yang dimaksudkan oleh PP No.27/2004 tersebut adalah contoh hak paten dalam pelaksanaan hak paten di bidang senjata api, amunisi, senjata kimia, senjata biologi, senjata nuklir, bahan peledak militer, perlengkapan militer, produk farmasi yang diperlukan untuk menanggulangi penyakit yang berjangkit secara luas, produk kimia yang berkaitan dengan pertanian, \& obat hewan yang diperlukan untuk menanggulangi hama dan penyakit hewan yang berjangkit secara luas.

Pelaksanaan hak paten oleh pemerintah tersebut ditetapkan melalui keputusan presiden (Kepres) dan tentu saja dilakukan dengan memberi imbalan kepada pemegang hak paten sebagai kompensasi yang besarnya ditentukan oleh pemerintah. Jika suatu paten diberikan kepada orang lain selain daripada orang yang berhak atas paten tersebut, maka orang yang berhak atas paten tersebut dapat menggugat ke Pengadilan Negeri (di Jakarta PN Jakarta Pusat/Niaga) agar paten tersebut berikut hak-hak yang melekat pada paten tersebut diserahkan kepadanya untuk seluruhnya atau untuk sebagian ataupun untuk dimiliki bersama. Berbeda dengan hak cipta yang melindungi sebuah karya, paten melindungi sebuah ide, bukan ekspresi dari ide tersebut. Pada hak cipta, orang lain berhak membuat karya lain yang fungsinya sama asalkan tidak dibuat berdasarkan karya orang lain yang memiliki hak cipta. Sedangkan pada paten, seseorang tidak berhak untuk membuat sebuah karya yang cara bekerjanya sama dengan sebuah ide yang dipatenkan. 


\section{Kerangka Hukum Internasional}

Kedudukan paten dalam kerangka hukum internasional, dapat dilihat dalam sejarah perkembangan HKI secara umum. Perhatian terhadap HKI sudah dimulai pada tahun 1883 dengan dibentuknya suatu badan yang bernama "the World Intellectual Property Organization (WIPO") yang dapat memberikan perlindungan atas adanya penemuanpenemuan di bidang ilmu pengetahuan dan teknologi pada saat itu. Misalnya ketika Johannes Brahms mampu menggabungkan simponi yang ketiganya, Robert Louis Stevenson menulis perbendaharaan pulau, dan John and Emily Roebling yang melengkapi konstruksi atas jembatan di Brooklyn New York. Penemuan-penemuan tersebut dirasakan perlunya adanya jaminan proteksi secara hukum.

Perlindungan terhadap hak kekayaan intelektual (HKI) sebagaimana yang diatur dalam konvensi-konvensi WIPO sesungguhnya adalah bersifat voluntatif (sukarela), yang artinya bahwa ketentuan-ketentuan hanya sebagai aturan-aturan dasar bagi negara-negara yang akan melaksanakan aturan tersebut di negaranya masing-masing. Akan tetapi dengan berjalannya waktu dan berkembangnya kemajuan ekonomi dunia, maka ketentuanketentuan dalam konvensi-konvensi WIPO menjadi bersifat compultatif (keharusan) yang artinya bahwa ketentuan-ketentuan tersebut wajib dilaksanakan bagi negara-negara yang sudah tergabung dalam keanggotaannya.

Perubahan sifat dari keberlakuan ketentuan-ketentuan yang berkaitan dengan perlindungan hak kekayaan intelektual (HKI) dimulai dengan telah dicapainya kesepakatan GATT (General Agreement on Tariff and Trade), kemudian setelah Konfrensi Marakesh pada bulan April 1994 disepakati pula kerangka GATT akan diganti dengan sistim perdagangan dunia yang dikenal dengan WTO (World Trade Organization). Indonesia sendiri telah meratifikasi konvensi pendirian WTO melalui Undang-undang Nomor : 7 Tahun 1994 tentang Pengesahan Agreement Establishing The World Trade Organization (Persetujuan Pembentukan Organisasi Perdagangan Dunia), yang diundangkan dalam Lembaga Negara Republik Indonesia 1994 Nomor: 57 tanggal 2 Nopember 1994.

Dalam struktur lembaga WTO terdapat Dewan Umum (General Council) yang berada di bawah Dirjen WTO. Dewan Umum ini selanjutnya membawahi tiga dewan, yang salah satu diantaranya adalah Dewan TRIPs (Trade Related Aspects of Intellectual Property 
Rights). TRIPs ini dapatlah dikatakan sebagai isu baru dalam kancah perekonomian internasional, di mana bahwa dimasukannya TRIPs dalam kerangka WTO lebih merupakan sebagai mekanisme yang sangat efektif untuk mencegah alih teknologi, yang memainkan peranan kunci dalam proses pertumbuhan dan pembangunan ekonomi.

Sangat pentingnya perlindungan internasional atas Kekayaan Intelektual (IP) menjadi bukti ketika dalam suatu pameran diluar negeri beberapa pemikir yang telah menemukan invensi dan inovasi baru yang menolak untuk hadir pada "the International Exhibition of Invention in Vienna" pada tahun 1873. Hal mana disebabkan suatu kehawatiran bahwa ide-ide mereka akan dicuri dan disebarluaskan secara komersil ke negara-negara lain.

Merupakan sesuatu hal yang wajar jika para penemu tidak bersedia memamerkan penemuannya sebelum adanya suatu jaminan atas keamanannya. Karena bagaimanapun harus diakui bahwa setiap ide-ide yang cemerlang dan kreatif yang datang dari seseorang atau sekelompok orang merupakan bentuk dari kemampuan intelektual manusia yang tidak semua orang bisa memiliki atau mempunyainya. Apalagi karya intelektual itu nantinya berguna dan memberi dampak baik dari berbagai aspek kehidupan. Dari itu, perlu adanya jaminan keamanan dan perlindungan. Jaminan keamanan inilah yang diharapkan, agar terdapat perlindungan secara menyeluruh.

Berkenaan dengan kepentingan tersebut, maka pada tahun 1883 ditetapkan sebagai lahirnya "the Paris Convention for Protection of Industrial Property", keputusan internasional yang pertama dibuat untuk membantu orang pada suatu negara dapat diberikan perlindungan pada negara-negara lain dalam bentuk "Hak Kekayaan Industri (industrial property rights)", seperti ; a) Invention (patents), b) Trademarks, c) Industrial designs. Kemudian pada tahun 1884 "the Paris Convention" yang memiliki 14 negaranegara anggota, yang dibentuk dalam suatu "Biro Internasional" untuk melakukan tugastugas admisnitrasi, seperti melakukan pertemuan-pertemuan organisasi dengan negaranegara anggota dalam rangka melakukan kordinasi tentang pentingnya perlindungan atas kekayaan industri. Dan dalam perkembangan selanjutnya keanggotaan dalam "the Paris Convention" terus bertambah sesuai dengan meningkatnya kebutuhan akan perlindungan kekayaan industri di negara masing-masing. 
Pada tahun 1886, dengan berkembangnya industri yang sangat cepat lahirlah ketentuan tentang hak cipta (copyrights) termasuk ke dalam arena internasional dengan "Berne Convention for the Protection of Literary and Artistic Works". Isi dari konvensi ini telah membantu kepentingan nasional dari negara-negara anggota yang memberikan perlindungan internasional atas hak-hak mereka dalam mengontrol, dan untuk menerima pembayaran, pada saat menggunakan kreativitas kerja mereka. Isi dari hak cipta seperti ; Pertama, novel-novel, cerita-cerita pendek, syair-syair, sajak-sajak; Kedua, lagu-lagu, opera, music, sonata, dan; Ketiga, gambar-gambar, lukisan-lukisan, seni pahat, pekerjaan arsitektur. Hal yang sama seperti "the Paris Convention", "the Berne Convention" dilengkapi dengan "Biro Internasional" untuk melakukan tugas-tugas administrasinya. Tahun 1893 telah dilakukan penyatuan dua biro-biro kecil untuk membentuk suatu organisasi internasional yang disebut "the United International Bureau for the Protection of Intellectual Property (yang disebut dalam nama Perancis sama dengan BIRPI). Yang bertempat di Berne, Switzerland, dengan memiliki 7 (tujuh) orang staf. Organisasi kecil ini adalah merupakan cikal bakal dari pada berdirinya "the world intellectual property organization(wipo)" "Paris Convention" yang di dalamnya mengatur tentang proses serta perlindungan atas hak-hak atas kekayaan intelektual khususnya di bidang industry (intellectual property rights of industrial) yang terdiri dari beberapa hak atas kekayaan intelektual termasuk di dalamnya adalah hak paten.

\section{Lisensi dan Kedudukan Hukum Bagi Pemegang Hak Paten.}

Perlu dipahami juga bahwa pemegang Paten berhak memberikan Lisensi kepada pihak lain berdasarkan perjanjian Lisensi selama jangka waktu Lisensi diberikan dan berlaku untuk seluruh wilayah Negara Republik Indonesia. Kecuali diperjanjikan lain, Pemegang Paten tetap boleh melaksanakan sendiri atau memberikan Lisensi kepada pihak ketiga lainnya. Paten dinyatakan batal demi hukum apabila Pemegang Paten tidak memenuhi kewajiban membayar biaya tahunan dalam jangka waktu yang ditentukan dalam Undang-undang ini. Paten dapat dibatalkan oleh Direktorat Jenderal untuk seluruh atau sebagian atas permohonan Pemegang Paten yang diajukan secara tertulis kepada Direktorat. Paten juga dapat dibatalkan oleh Pengadilan Niaga apabila ada gugatan pembatalan Paten. 
Apabila Pemerintah berpendapat bahwa suatu paten di Indonesia sangat penting artinya bagi pertahanan keamanan negara dan kebutuhan sangat mendesak untuk kepentingan masyarakat, pemerintah dapat melaksanakan sendiri paten yang bersangkutan dengan memberitahukan secara tertulis hal tersebut kepada pemegang paten dan pemberian imbalan yang wajar kepada pemegang paten.

Bahwa dalam ketentuan Undang-Undang Paten maupun Konvensi Paris telah diatur tentang kedudukan pemegang hak paten. Dari mulai apa yang dimaksud dengan Paten, syarat-syarat, cara mengajukan permonan pendaftaran, pemeriksaan, pengumuman Paten sampai bagaimana cara melaksanakan dan mengalihkan Paten. Dari kedua ketentuan tersebut telah menegaskan bahwa pemegang hak Paten memiliki kedudukan yang kuat, selama pemegang Paten senantiasa berpedoman kepada ketentuan hukum yang berlaku. Namun demikian, Konvensi Paris tidak memuat ketentuan pokok mengenai perlindungan paten seperti pokok masalah yang dipatenkan, berlakunya hak-hak paten yang diberikan dan jangka perlindungan hak-hak paten. Konvensi Paris memuat ketentuan-ketentuan yang tidak jelas mengenai pemberian lisensi tentang paten yang tidak digunakan. Beberapa argument telah diajukan pada saat Konvensi Paris, tetapi hal ini mengalami kebuntuan tanpa ada penyelesaian dikarenakan adanya perbedaan pendapat yang tajam antara negaranegara maju dengan negara-negara berkembang. Beberapa upaya lebih lanjut untuk menghindari kebuntuan, tetapi gagal dikarenakan masih adanya perbedaan yang tajam diantara mereka. Untuk mencari solusi atas permasalahan ini disediakan satu forum tingkat tertentu yang disebut TRIPS Negotiation.

\section{E.Perlindungan Hukum Bagi Pemegang Hak Paten.}

Lahirnya Undang-Undang Paten di Indonesia dilandasi oleh kebutuhan bangsa Indonesia untuk memiliki suatu sistem perlindungan hukum bagi penemu dalam bidang teknologi dalam proses industrialisasi. Hal ini dapat dilihat dengan diundangkannya Undang-Undang Nomor 14 tahun 2001 Tentang Paten (selanjutnya ditulis UU Paten 2001). Melalui UU Paten 2001 banyak sekali penyempurnaan, penambahan dan penghapusan terhadap Undang-undang Paten yang dahulu yaitu Undang-Undang Nomor 6 Tahun 1997 tentang Paten. Adapun tujuan pembuatan Undang-Undang Paten 2001 ini adalah untuk 
memberikan perlindungan hukum yang memadai terhadap pemegang paten serta untuk menyempurnakan terhadap kekurangan atas beberapa ketentuan yang tidak sesuai dengan kebutuhan praktek internasional.

Dengan adanya hak prioritas pemegang Paten, maka diberikan perlindungan oleh hukum nasional (UU Paten) maupun hukum internasional (Konvensi Paris) sebagai pendaftar pertama (first to file) untuk mendapatkan hak sebagai pemegang Paten. Pendaftaran mana tentunya merujuk kepada tata cara pendaftaran yang ditentukan oleh Undang-Undang Paten. Sebagai pemegang Paten (Inventor) juga diberikan perlindungan oleh Undang-undang terhadap Invensi-invensi baru di bidang teknologi yang dapat saja invensi tersebut akan merugikan Inventor. Dan kalau itu terjadi maka Inventor dapat mengajukan penyelesian sengketa ke pengadilan niaga. Dalam rangka WTO telah pula diatur tentang perlindungan atas Intellectual Property Rights (IPR) hal ini diimplementasikan dengan adanya TRIPS (Trade Realated All Aspect Property Rights).

\section{F. Penutup}

Paten adalah hak yang dimiliki seorang Inventor atas suatu Invensi di bidang teknologi, dapat diaplikasikan sendiri atau dikuasakan kepada orang lain, serta memiliki nilai ekonomi. Dan telah ditetapkan kepemilikan haknya oleh pemerintah berdasarkan ketentuan hukum yang berlaku. Pemegang hak Paten (inventor) diberikan perlindungan atas dasar hukum nasional ataupun hukum internasional sebagai hak prioriotas untuk melaksanakan sendiri atau secara bersama-sama invensi-nya atau memberikan kuasa kepada orang lain untuk melaksanakannya. Kedepan sudah sepantasnya negara serius dalam mengatasi permasalahan Paten ini, hal ini bertujuan agar para pemegang Paten tidak merasa disepelekan atas karya-karyanya. Indonesia sudah mempunyai perangkat peraturan perundang-undangan yang cukup di bidang Paten. Dengan demikian sudah saatnya perlindungan Paten betul-betul dapat ditegakkan. Kemudian juga negara harus dapat memberikan pemahaman kepada masyarakat sebagai penemu untuk sungguh-sungguh menghasilkan paten dan menjadikannya sebagai pemenuhan untuk meningkatkan kesejahteraan. 


\section{Daftar Pustaka}

Insan Budi Maulana. 1998. Lisensi Paten. Bandung: Citra Adtya Bhakti,.

John Locke, 1997. "Summa Theologiae",dalam Sonny Keraf, Hukum Kodrat dan Teori Hak Milik Pribadi. Jogjakarta: Kanisius.

Marshall Leaffer, 2007. Understanding Copyright Law. Oxford Legal Publisher.

Mahadi. 1981. Hak Milik dalam sistem Hukum Perdata Nasional. Jakarta: BPHN.

Oentoeng Soerapati. 1999. Hukum Kekayaan Intelektual dan Alih Teknologi.Salatiga: FH, UNKRIS Satya Wacana.

Shidarta, 2009, Misnomer dalam Nomenklatur dan Penalaran Positivisme Huku. Jakarta: Yayasan Obor Indonesia.

Rachmadi Usman. 2003. Hukum Hak atas Kekayaan Intelektual Perlindungan dan Dimensi Hukumnya di Indonesia. Bandung: Alumni.

Titik Triwulan Tutik. 2008. Hukum Perdata dalam Sistem Hukum Nasional. Jakarta: ,Kencana.

\section{Peraturan:}

Kitab Undang-Undang Hukum Perdata (Begerlijk wet Book).

Undang-undang No.14 Tahun 2001 tentang Paten (UUP).

Jurnal:

Monika Suhayati., Perlindungan Hukum Terhadap Hak Ekonomi Pemilik Hak Terkait Dalam Undang-Undang Nomor : 28 Tahun 2014 Tentang Hak Cipta. Jurnal Ilmiah Hukum Negara Hukum (Membangun Hukum Untuk Keadilan dan Kesejahteraan) Volume 5 Nomor : 2 Nopember 2014 . Pusat Kajian, Pengolahan Data dan Informasi (P3DI) Sekretariat Jenderal Dewan Perwakilan Rakyat Republik Indonesia

Oksidelfa Yanto. Tinjauan Yuridis Undang-Undang Nomor : 15 Tahun 2001 Tentang Merek : Sisi Lain Kelemahan Sistem First to File dalam Perlindungan Hukum atas Merek sebagai Bagian dari Hak atas Kekayaan Intelektual (HaKI). ADIL Jurnal Hukum Volume 3 Nomor :1 Juli 2012 Fakultas Hukum Universitas YARSI Jakarta. 